\title{
Advantages and Optimization Strategies of Green Construction in Architectural Engineering
}

\author{
Li Shilei \\ School of Architectural and Survey Mapping Engineering, Beijing Polytechnic College, Beijing, China
}

Keywords: architectural engineering; green construction; sustainable development

\begin{abstract}
Green construction is the current development trend of the construction industry. On the one hand, it is due to the improvement of construction technology. On the other hand, residents are increasingly demanding the residential environment. Therefore, green construction not only meets the environmental protection needs of modern people, but also reduces energy consumption and realizes the sustainable development of the construction industry. Compared with traditional construction methods, green construction has great advantages, and it focuses on the protection of the environment and can achieve the desired overall benefits.
\end{abstract}

\section{Introduction}

Green construction refers to construction activities that use advanced technology and scientific management methods to save energy and reduce environmental pollution in order to ensure construction quality and safety in architectural engineering process. Moreover, the green construction is also the current development direction of architectural engineering in China. The use of green construction measures for architecture will not only reduce the use of building materials, but also save material processing costs and transportation costs, thereby increasing the effective utilization of land.

\section{The Basic Overview of Green Construction}

\subsection{The connotation of green construction}

With the gradual development of China's economic construction, various construction projects have been gradually implemented, which has exerted great pressure on the environment and caused great damage to the environment. At the same time it has also affected the normal life of the people and the sustainable development of the economy. The concept of green and environmental protection has gradually gained attention, and green construction has been promoted and applied in architectural projects.

The contents of green construction mainly include four aspects: first, using green building materials and equipment; second, saving resources and reduce energy consumption; third, environmental protection should be implemented as much as possible in the construction process; Fourth, we should formulate and improve the construction process and construction methods, while selecting the best construction equipment and construction materials through scientific and technical means and management methods, in accordance with the requirements of the country's green civilization construction. Green construction is the concrete application of architectural engineering construction in China's sustainable development strategy. This is a new type of construction method, which is in line with the national environmental protection construction concept. The green construction method is mainly embodied in construction methods and technical indicators, and can meet the requirements of national environmental protection. Protect the environment and improve the utilization of resources through the green construction method to, so as to enhance the construction level of the construction project. 


\subsection{The difference between green construction and traditional construction}

The difference between green construction and traditional construction is that the target of traditional construction is cost, duration, safety and quality. According to the requirement of green construction, the protection of the environment and the saving of construction methods are fully reflected. At the same time there is a certain gap between the savings in green construction and the traditional sense. The savings of traditional construction refer to the reduction of costs and the consumption of building materials. The term "economy" in green construction refers to the goal of environmental protection and the importance of sustainable development. It is to create a new type of construction mode that minimizes the impact on the natural environment and human society and makes efficient use of resources. It focuses on reducing the consumption of resources during the construction process, thereby effectively enhancing the protection and use of the environment, and ultimately effectively reducing the adverse impact on the environment. For the construction party, the implementation of the green construction concept requires increasing the cost of the project construction, the needs of environmental protection requires more technical indicators, so that more economic costs need to be invested in terms of green construction and traditional construction methods. But this kind of investment will bring in a big return for the country's environmental development.

\section{The Advantages of Green Construction in Architectural Engineering}

Green construction has a variety of advantages in the way of architectural projects, and it is also a catalyst for the development of the company. Its superiority is mainly reflected in the fact that green construction can guarantee the safety of construction projects. Green construction saves construction materials. Green construction reduces noise pollution and green construction protects construction soil. The following analysis was conducted from these four points.

\subsection{Green construction can guarantee the safety of architectural projects}

To ensure construction safety is a prerequisite for the construction of a architectural project, so no matter what construction technology is used, safety must be taken into account. The first principle of green construction is to ensure construction safety and protect the safety of construction workers and the construction environment. In the implementation of the green construction process, safe and non-polluting building materials should be used, and some well-designed construction equipment with good man-machine relations should be added to facilitate the construction personnel to perform well and at the same time avoid potential safety hazards during construction. This largely protects the personal safety of construction workers. In addition, the construction personnel can make full use of the green construction materials and construction equipment during the construction process, and can promote the construction workers to more actively participate in the work process, and ultimately promote the construction program to be carried out normally and safely. Therefore, green construction can not only protect the environment and effectively use resources, but also protect the safety of construction workers, so as to achieve the sustainable development of the construction industry.

\subsection{Green construction saves construction materials}

As a new type of construction technology, green construction technology has the advantage that traditional construction technology is difficult to compare. For example, green construction can transform construction materials and combine them with new technologies to reduce the use of building materials. When designing deep foundation pits for high-rise buildings, a combination of new technologies and retrofitting of building materials can be used. While protecting the environment, it can also save some building materials. This not only saves the cost of building materials for construction projects, but also improves the economic returns of construction companies to a certain extent. 


\subsection{Green construction reduces noise pollution}

Noise pollution is one of the important components of environmental pollution. It not only affects people's work and study, but also brings many problems to people's daily lives. Therefore, solving the problem of noise pollution is also a powerful measure to protect the environment. Compared with traditional construction techniques, due to the use of low-noise equipment in green construction in architectural projects, the decibels of sound during construction are relatively low and will not affect people's normal rest. If it is night, if the construction site is too close to residential buildings and low-noise equipment still has an impact on people's lives, measures will be taken to stop the construction to ensure the residents' normal rest.

\subsection{Green construction protects construction soil}

Traditional construction technology will cause serious damage to the soil, while green construction can not only protect the environment from pollution, but also avoid soil erosion and underground environmental pollution. On the one hand, green construction technology uses the method of planting green vegetation to solidify the soil formed during the construction process. On the other hand, during construction, surface drainage pipes are laid to protect groundwater from contamination. Moreover, materials used in buildings that cause pollution to the construction environment cannot be discarded on construction sites. These green construction requirements ensure that the construction environment is not polluted and destroyed, and the best construction results are achieved.

\section{Optimization of Green Construction in Architectural Engineering}

In view of the advantages of green construction in building construction, it is necessary to actively explore the strategic approach of green construction in corporate construction.

It is mainly reflected in enhancing green construction awareness of construction workers, establishing a sound green construction management system, strengthening the unity and cooperation of all parties to jointly promote green construction and actively research innovative research on green construction technology and management methods. The following analysis was conducted from these four points.

\subsection{Strengthen the construction workers' consciousness of green construction}

The construction of the architectural projects will ultimately be implemented on specific construction personnel. Even though effective green regulations and technical methods have been formulated, if construction workers do not uphold the concept of green construction at the construction site, they will cause significant pollution to the environment, which is against the implementation of green environmental awareness. The construction unit must also strengthen the publicity of green construction and enhance the green construction awareness of construction personnel. In the acceptance of the project, the employees of the unit must also be trained in green construction, so that the employees understand the concept of green construction, and demonstrate the construction products with the green construction concept to the employees, so that the construction personnel can understand the environment benefits, economic benefits and social benefits brought by the green construction. Only in this way can the construction personnel establish the value concept of green construction, and thus use the green construction technology to ensure the construction safety of the construction project during the construction process.

\subsection{Establish a sound green construction management system}

The green construction management system plays an important guiding role in the construction of the project. With the country's emphasis on environmental protection, many business units have now established a green and healthy development concept. However, in the specific implementation process, there are still problems, which cause some pollution to the environment. Therefore, it is required to establish a sound green construction management system to strengthen supervision and cooperation among various departments of construction companies, fully implement effective 
corporate construction management concepts, strengthen the regular inspection and acceptance of the company's construction work, strictly supervise and control it to ensure the effective implementation of green construction technology. And effectively implementing green construction techniques to enhance the quality of employees' work, enhance the innovativeness of employees' work process, and using material rewards and spiritual rewards to promote the improvement of employees' professional qualities. For employees who violate construction regulations, environmental violations are caused by their illegal construction activities, and they bring security risks to the construction environment. Strict punishment measures are also taken to prevent the occurrence of such violations. The provisions of national laws and regulations at the green technology promotion level can provide effective engineering guidance for the green construction of architectural projects. This can fully reflect the responsibilities of all parties involved in the construction, coordinate with the effective implementation of the company's construction methods, and integrate the forces of various parties to effectively promote the effective implementation of the construction plan.

\subsection{Strengthen the unity and cooperation of all parties to jointly promote green construction}

The promotion of green construction in architectural projects requires the coordinated advancement of all parties. First, it is necessary to strengthen the government's support, it requires the government to use sufficient macro-control power to formulate a green construction management method, formulate green construction method details for the construction of construction projects, and provide sufficient incentive and encouragement to good enterprises. The development of effective codes of conduct and safety norms will enable all forces in society to actively participate in the construction of green enterprises. The second is to strengthen the market tilt. In the traditional market competition, there is a low-price bidding method that takes the construction period as the leading factor. This is contrary to the green construction companies, which should be phased out and create favorable conditions for the development of green construction units. Strengthen owner-led. In the process of construction projects, the investor of project project is in a dominant position. The implementation of the green project construction method needs the full support of the owner and requires support from the development mode and funds, so as to ultimately ensure that the green project can be strictly implemented in accordance with the established plan. Finally, it is to strengthen the whole process of architectural project construction, establish a complete organization system for the construction of green enterprises, formulate clear goals in a timely manner, put the responsibilities of each implementing party in place, establish an effective management system to ensure the effective implementation of green construction companies.

\subsection{Actively research the innovation of green construction technology and management methods}

The implementation of green construction requires the implementation of green construction technology, which is an important basis for the implementation of green construction methods. The traditional construction methods mainly focus on the project duration, project quality, engineering safety and the company's own cost control, and generally do not fully pay attention to the objectives of corporate environmental protection. In the process of promoting the traditional technology, construction techniques, there is generally a lack of adequate attention to environmental protection. In the process of promoting green construction, it is required that the traditional construction technology and management methods be improved up to the green environmental protection level, and the construction process methods should be created based on the concept of green environmental protection. It fully strengthens the research and innovation of green environmental protection technology. It is mainly reflected in research and innovation development of resource regeneration technology, green building materials, and green construction equipment. 


\section{Conclusion}

Green construction is an effective measure to ensure the successful construction of the architectural projects. It is also an important method for ensuring construction safety and construction environment from being contaminated. Green construction is a modern construction concept. It not only requires that environmental protection measures be taken during the construction process, but also requires construction personnel to carry out safety construction in strict accordance with relevant regulations, so as to ultimately achieve the goal of green construction and improve construction quality of architectural projects and to promote the sustainable development of the construction industry.

\section{References}

[1] Lei An. Application of green construction technology in Architectural Engineering [J]. Jiangxi Building Materials, 2014, 17:55.

[2] Haiping Chen. Discussion on application of green construction technology in Architectural Engineering [J]. Information of China Construction, 2015, 05:77-78.

[3] Xuwen Xiao, Dakuo Feng. Analysis and suggestions for green construction of architectural projects [J]. Construction Technology, 2013, 01:12-15.

[4] Xiaobing Wen. Application of green construction technology in Architectural Engineering [J]. China Homes (Late edition), 2014, 06:321-322. 